\title{
GLOBAL CLIMATE CHANGE: MODELLING THE POTENTIAL RESPONSES OF AGRO-ECOSYSTEMS WITH SPECIAL REFERENCE TO CROP PROTECTION
}

\author{
J. Goudriaan \\ Department of Theoretical Production Ecology, Wageningen Agricultural University, POB 430, 6700AA Wageningen, \\ The Netherlands \\ $\&$ \\ J. C. Zadoks \\ Department of Phytopathology, Wageningen Agricultural University, POB 8025, 6700 EE Wageningen, The Netherlands
}

(Received 10 August 1993; accepted 20 December 1993)

\begin{abstract}
Pests and diseases reduce yields to lower levels than those that could have been potentially obtained, given the restrictions of climate, nutrients and crop varieties. Climatic change not only affects the potential yield levels, but it may also modify the effects of pests and diseases. Modelling can serve as a tool to integrate these processes, ranging from simple removal of plant material to subtle toxic and hormonal effects. Modelling can help to quantify different modes of action such as on photosynthesis, root activity, assimilate partitioning, morphology, and their interactions. As to climatic change, little is known about pests, diseases and weeds. If climatic change causes a gradual shift of agricultural regions, crops and their associated pests, diseases and weeds will migrate together, though at different rates maybe. To a limited extent, new outbreaks can be foreseen given the changed environmental conditions. Methodology is available, and some interesting results are on record. Specific changes such as an increase in the $\mathrm{CO}_{2}$ content in the air and in $U V$ radiation are not likely to have large effects. Increasing atmospheric $\mathrm{CO}_{2}$ reduces crop nitrogen content, which may retard many pests and diseases, and change the composition of the weed flora which accompanies crops. Some cautionary remarks are made to avoid jumping to conclusions.
\end{abstract}

Keywords: Carbon dioxide, diseases, greenhouse effect, nitrogen, pests, water, weeds.

\section{INTRODUCTION}

A gradual but accelerating increase of $\mathrm{CO}_{2}$ and of other greenhouse gases in the atmosphere has been well documented to occur since the industrial revolution. The inference is that the natural and life-sustaining greenhouse effect will be enhanced, the earth will warm up, and climates will change (Houghton et al., 1990). For the present discussion we accept this inference as a baseline truth, and therewith the various estimates for rates of change.

This paper considers the effects of climate change on (i) crop production, (ii) yield reduction by pests, diseases and weeds, (iii) distribution of crops, pests and diseases. The use of modelling as a tool will be illustrated throughout.

Present-day knowledge allows for considerable extrapolation regarding weeds, pests and diseases, and certainly permits a warning for some nascent misconceptions. We will first quote some current extrapolations of climatic change, then consider what might happen to agricultural crops, and finally see what such events may mean in terms of weeds, pests and diseases.

\section{CROP PRODUCTION}

Physiological effects of rising $\mathrm{CO}_{2}$

Rising $\mathrm{CO}_{2}$ in itself has a large effect on plant growth, even if there were no climatic change at all. Atmospheric $\mathrm{CO}_{2}$ is the sole source of carbon for plant growth. In atmospheric air the concentration of $\mathrm{CO}_{2}$ is low, only about $0.035 \%\left(350 \mu \mathrm{mol} \mathrm{mol}{ }^{-1}\right)$. Any increase in this low concentration is likely to benefit plant growth, though differences between species exist (Poorter, 1993). However, several other effects of $\mathrm{CO}_{2}$ exist and interfere with the positive baseline effect. For instance, higher $\mathrm{CO}_{2}$ levels often lead to a slightly reduced nitrogen content of plant tissue. In its turn, this may affect the impact of sucking insects and pathogenic fungi. We suggest that each (foliar) fungal pathogen has its own nitrogen optimum in the leaves, since, for example, speckled leaf blotch (Septoria tritici) of wheat thrives at high nitrogen levels which reduce glume blotch (Septoria nodorum) on leaves (Zadoks, unpublished). Sucking insects such as aphids utilize nitrogen and excrete most of the sugars of the phloem sap (Rossing \& van de Wiel, 1990; Dik et al., 1991). At lower nitrogen levels 
there-may be more-excretion, more honeydew and more sooty mould, and thus more damage to host plants. Simultaneously the host plants may become less attractive to the insects (Tripp et al., 1992). The net result of these two countervailing effects is unknown. This paper will consider some of these ecophysiological interactions more closely and discuss their potential impacts.

Interaction of rising $\mathrm{CO}_{2}$ with other limiting factors

There is no doubt about the existence of a positive $\mathrm{CO}_{2}$ effect on final dry matter formation under favourable conditions for plant growth (Lemon, 1983), as in intensive agriculture. Whether this baseline or $\mathrm{CO}_{2}$ fertilization effect will remain operative under conditions where plant growth is limited by other factors is questionable. Under most circumstances a part of the growth stimulation by increased $\mathrm{CO}_{2}$ is maintained, even if growth conditions are not optimal.

In biology and agronomy growth limitation by a single factor is well known and expressed in Liebig's law. This notion is so pervasive that it has supplanted the recognition of the fact that co-limitation by several factors at a time (Mitscherlich's law) exists as well (de Wit, 1992). Figures 1 and 2 show examples of colimitation.

Water

Photosynthesizing plant cells must absorb atmospheric $\mathrm{CO}_{2}$ by dissolving it in their cell solution for further processing by the photosynthetic machinery. The cell solution is a watery substance, and by exposing the cell surfaces to the air the plant will inevitably lose water by evaporation. The rate of water loss from a wet surface is high indeed. In fact, land plants have protected themselves from drying out by the formation of a dry epidermis on either side of the leaves. This epidermis contains stomatal apertures to permit entrance of $\mathrm{CO}_{2}$. The surface area occupied by the stomatal apertures

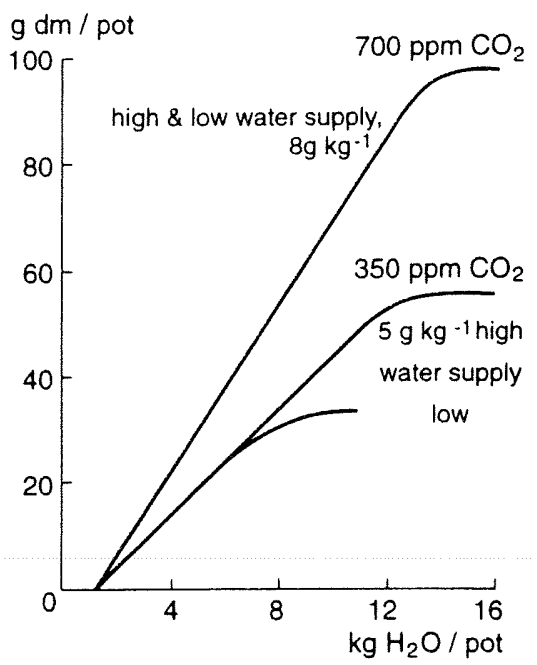

of a-leaf is usually less than-1\%. Yet the reduction of $\mathrm{CO}_{2}$ uptake by this impediment is much less than one might think: $10-30 \%$ only and definitely not $99 \%$. The reduction of evaporation is much larger, up to $90 \%$, according to circumstances. Clearly, this morphological adaptation of plants to life on land has strongly improved their water use efficiency. A further optimization was achieved by active control of stomatal aperture. During the night, for instance, the stomatal apertures are closed so that almost no water loss occurs during a period when photosynthesis is impossible. A typical secondary effect of raising $\mathrm{CO}_{2}$ is partial stomatal closure (Raschke, 1975; Morison, 1987). The degree of opening can be considered as a compromise in the balance between limitation of water loss and admission of $\mathrm{CO}_{2}$ (Wong, 1979).

In spite of these adaptations, the ratio between water loss and carbon gain is still very large, due to the low concentration of atmospheric $\mathrm{CO}_{2}$. The difference in partial vapour pressure inside and outside the leaves is typically a factor of at least one hundred larger for water than for $\mathrm{CO}_{2}$ and the gradients run in opposite directions. This simple physical fact explains the very large water requirements of plants, amounting to hundreds of kilograms of water transpired per kilogram of dry matter formed. When the ambient $\mathrm{CO}_{2}$ concentration rises, this ratio is improved, leading to better plant growth even under conditions of water shortage (Gifford, 1979). This response indicates a Mitscherlich type of interaction between water and $\mathrm{CO}_{2}$. For water limited conditions, plant biomass increases in proportion to cumulative water consumption, but with a slope that increases for higher atmospheric $\mathrm{CO}_{2}$ (Fig. 1). Here, the law of the minimum is not valid.

\section{Radiation}

Under increased atmospheric $\mathrm{CO}_{2}$ concentration, the efficiency of other factors is often improved too. Both light and $\mathrm{CO}_{2}$ are often suboptimal and consequently photosynthesis is stimulated by an increase in ambient

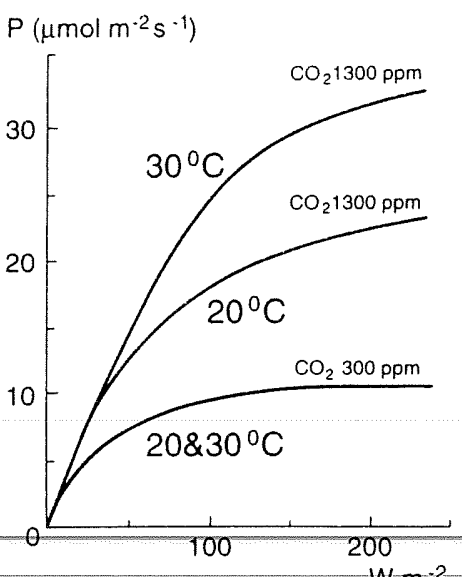

Fig. 1. Schematic representation of dry matter accumulation (subsequent harvests, grams dry matter per pot) of potted Faba bean plants in response to water supply (kg water per pot) for two $\mathrm{CO}_{2}$ levels and two water supply levels. After Goudriaan and Bijlsma, 1987.
Fig. 2. Schematic representation of photosynthesis in response to incoming radiation at two temperatures and two $\mathrm{CO}_{2}$ levels. After Goudriaan and Unsworth (1990). 


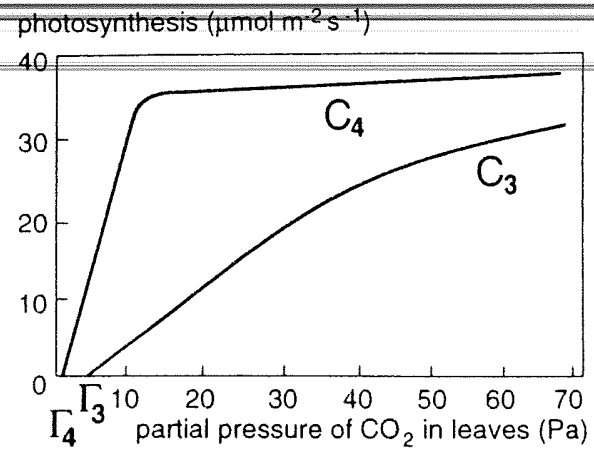

Fig. 3. Schematic representation of responses of $\mathrm{CO}_{2}$ uptake rate to ambient $\mathrm{CO}_{2}$ concentration in $\mathrm{C}_{3}$ and $\mathrm{C}_{4}$ plants. After Goudriaan and Unsworth (1990). The $\mathrm{CO}_{2}$ compensation points $\Gamma$ are indicated for either plant type.

$\mathrm{CO}_{2}$ (Fig. 3; Farquhar \& von Caemmerer, 1981). It appears that this stimulation does not only occur under high but also under low light conditions, at least in $\mathrm{C}_{3}$ plants. $C_{3}$ plants, in contrast to $C_{4}$ plants, exhibit photorespiration, leading to a much higher level of the $\mathrm{CO}_{2}$ compensation point $\Gamma$ (Fig. 3). In $\mathrm{C}_{3}$ plants the value of $\Gamma$ is about $50 \mu \mathrm{mol} \mathrm{mol}{ }^{-1}$ at $25^{\circ} \mathrm{C}$ in contrast to only $5 \mu \mathrm{mol} \mathrm{mol}^{-1}$ in $\mathrm{C}_{4}$ plants. The initial light use efficiency increases with $\mathrm{CO}_{2}$ in proportion with the quotient $\left(\left[\mathrm{CO}_{2}\right]-\Gamma\right) /\left(\left[\mathrm{CO}_{2}\right]+2 \Gamma\right)$ (Goudriaan et al., 1985). This is a major reason why the stimulatory effect of increasing $\mathrm{CO}_{2}$ on photosynthesis is stronger under high temperatures (Fig. 2). Photorespiration occurs simultaneously with real photosynthesis, and shows up in a reduction in the light use efficiency. This interaction indicates a Mitscherlich type of colimitation by radiation and atmospheric $\mathrm{CO}_{2}$, rather than the law of the minimum. Saturation of the $\mathrm{CO}_{2}$ effect does occur, as in $\mathrm{C}_{3}$-plants the light saturated rate of photosynthesis increases with $\mathrm{CO}_{2}$, first linearly from $\Gamma$ up to a $\mathrm{CO}_{2}$ concentration of about $600-1000 \mu \mathrm{mol} \mathrm{mol}^{-1}$ and then tapers off (Fig. 3).

$\mathrm{C}_{4}$-plants (Table 1) have a higher affinity to $\mathrm{CO}_{2}$ (Goudriaan et al., 1985). There is palaeological evidence that the $C_{4}$ plants evolved in the late Tertiary (Nambudiri et al., 1978), presumably as an adaptation to $\mathrm{CO}_{2}$ concentrations as low as $200 \mu \mathrm{mol} \mathrm{mol}^{-1}$. Although mainly found in tall grasses, the $C_{4}$ character independently evolved in other plant genera (Moore. 1982) such as the Chenopodiaceae growing in saline conditions. The $\mathrm{C}_{4}$ plants mainly grow in hot and

Table 1. Some major $C_{3}$ and $C_{4}$ plants among crops and weeds (Downton, 1975; Holm et al., 1977)

\begin{tabular}{|c|c|}
\hline Crops & Weeds \\
\hline $\mathrm{C}_{3}$ Rice, wheat & Goosefoot (Chenopodium album) \\
\hline Potato, cassava & Bindweed (Convulvulus arvensis) \\
\hline Sugarbeet, soybean & Waterhyacinth (Eichhornia crassipes) \\
\hline \multirow{4}{*}{$\begin{array}{l}\mathrm{C}_{4} \text { Maize, sugarcane } \\
\text { Sorgtim, mintet }\end{array}$} & Barnyard grass (Echinochloa crus-galli) \\
\hline & Johnson grass (Sorghum halepense) \\
\hline & Crabgrass (Digitaria sanguinalis) \\
\hline & Purslane (Portulaca oleracea) \\
\hline
\end{tabular}

dry enviromments (savanna's), and in physiologically similar habitats such as salt marshes and salt plains (Aber \& Melillo, 1991). At a given photosynthetic rate, $\mathrm{C}_{4}$ plants can close their stomata about twice as much as $C_{3}$ plants can, so that their water use efficiency is nearly twice as high (Loomis \& Connor, 1992).

\section{Nutrients}

When there is a nutrient shortage especially of phosphorus and of potassium, crop growth is severely limited and there is very little stimulation by $\mathrm{CO}_{2}$. However, nitrogen differs from other nutrients in that a small positive $\mathrm{CO}_{2}$ effect remains, even under rather severe nitrogen shortage. The background of this observation is that the plants economize on the carboxylation enzyme Rubisco, which normally contains almost half the total leaf nitrogen. In accordance with this photosynthetic role of nitrogen, the nitrogen content in leaf tissue is lower for plants grown under high $\mathrm{CO}_{2}$ than under low $\mathrm{CO}_{2}$ (Lemon, 1983; Larigauderie et al., 1988). Also, starch is further accumulated (Ehret \& Jolliffe, 1985).

Some 200 years ago the $\mathrm{CO}_{2}$ concentration was much lower $\left(285 \mu \mathrm{mol} \mathrm{mol}{ }^{-1}\right)$ than today $\left(350 \mu \mathrm{mol} \mathrm{mol}^{-1}\right)$. This rise in $\mathrm{CO}_{2}$ has had an effect on the $\mathrm{C}: \mathrm{N}$ ratio. Peñuelas and Matamala (1990) found a significantly lower $\mathrm{C}: \mathrm{N}$ ratio in herbarium material from 200 years ago than in recent plants of the same species growing in similar natural circumstances. Van der Burgh et al. (1993) found evidence of a morphological adaptation of the stomatal index in fossil Quercus petreae leaves to atmospheric $\mathrm{CO}_{2}$ content in material dating back to 10 million years ago. So far, we have no information on the meaning of this morphological adaptation in terms of stomatal functioning, $\mathrm{CO}_{2}$ uptake and transpiration rate.

\section{Maintenance of the positive $\mathrm{CO}_{2}$ effect throughout growth}

There is evidence of both negative and positive adaptations during prolonged cultivation under increased $\mathrm{CO}_{2}$. Photosynthesis per unit leaf area was mostly found to be smaller in plants adapted to high $\mathrm{CO}_{2}$ (Wong, 1979; Mortensen, 1983) than in non-adapted plants (when measured under equal circumstances). Adapted plants seem to be spoiled and lose their high $\mathrm{CO}_{2}$ response. This loss is attributed to a reduction of the nitrogen containing carboxylation enzymes. However, Valle et al. (1985) and Campbell et al. (1988) found a positive adaptation in soybean, and Arp and Drake (1991) likewise in the salt marsh sedge Scirpus olneyi.

In general, leaves grown at a higher $\mathrm{CO}_{2}$ concentration maintain a higher rate of photosynthesis when that rate is measured at the same higher $\mathrm{CO}_{2}$ level. In an experimental study during 4 years of continued exposure of a natural salt marsh vegetation to high $\mathrm{CO}_{2}$, Arp and Drake (1991) found no decline in the $\mathrm{CO}_{2}$ stimulus of either photosynthesis or water use efficiency (Arp, 1991). 


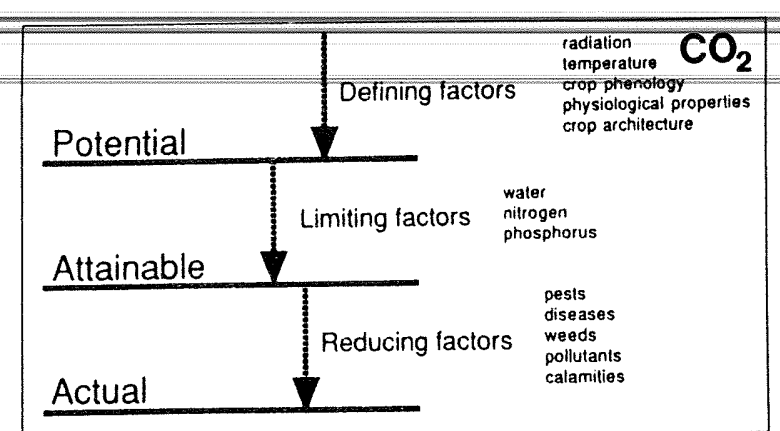

Crop production

Fig. 4. Crop production levels (van der Werf et al., 1990).

\section{Some modelling aspects}

\section{Hierarchical modelling}

The mechanistic modelling process follows several hierarchies. One hierarchy (Fig. 4) begins with normal, healthy crops not subject to any constraint, and successively introduces yield defining, limiting and reducing factors. Another hierarchy has three steps. The first is the individual leaf, without or with constraint, often measured in a small hand-hold gas exchange chamber. The second is the crop canopy, again without or with constraint, often measured in large, mobile gas exchange chambers placed in the field. The third is the field experiment with continuous crop, pest, disease and environmental monitoring for multilocational and multiseasonal verification. A third hierarchy may be found in the physiological processes affected by the abiotic and biotic constraints (Table 2; Boote et al., 1993).

\section{Carbon assimilation}

The process of $\mathrm{CO}_{2}$-assimilation of a crop canopy is the result of the combined action of all photosynthesizing organs. They respond almost instantaneously to environmental factors, such as radiation, $\mathrm{CO}_{2}$ and temperature. These external factors can fluctuate rapidly and so can the rate of assimilation. In contrast, plant status variables such as leaf area or nitrogen content are much more stable and vary little within a single day. Accordingly, in a plant growth model, the crop canopy is represented by a set of state variables upon which the environment exerts its influence. Canopy assimilation is modelled by using a subroutine that is called at representative moments during the day. The frequency of such moments will depend on the fluctuation of the environment, especially of radiation (Spitters et al., 1986), and also on the desired precision of the calculations in the time domain.

\section{Light gradients}

Within a plant canopy at any one moment an extreme variation in leaf irradiation can occur, especially when the sun shines. Light saturation of leaf photosynthesis must then be taken into account. The effect of scattered light, leading to 'second-hand' irradiance on shaded leaves, is also to be included. The whole range of light intensities that exist at any one moment in a crop
Table-2. Principal processes in ptants which can be affected by growth-reducing factors. After Rossing et al. (1992) (Table 11.1) which is based on an earlier classification by Boote et al. (1983)

\begin{tabular}{|c|c|}
\hline Processes & Growth-reducing factors \\
\hline \multicolumn{2}{|l|}{ Carbon economy } \\
\hline \multicolumn{2}{|l|}{ Photosynthesis } \\
\hline $\begin{array}{l}\text { Light interception } \\
\text { and distribution }\end{array}$ & Weeds, foliar fungi, leaf-eating insects \\
\hline $\begin{array}{l}\text { Foliar } \mathrm{CO}_{2} \\
\quad \text { assimilation }\end{array}$ & $\begin{array}{l}\text { Fungal and viral pathogens, } \\
\text { phloem-feeding insects, air pollution }\end{array}$ \\
\hline Respiration & $\begin{array}{l}\text { Fungal and viral pathogens, spidery } \\
\text { mites, phloem feeders }\end{array}$ \\
\hline Allocation & Biotrophic fungi, viruses, phloem feeders \\
\hline Transport & Phloem feeders \\
\hline \multicolumn{2}{|c|}{ Water and nutrient economy } \\
\hline Uptake & Root pathogens, nematodes \\
\hline Transport & Vascular wilt diseases \\
\hline $\begin{array}{l}\text { Transpiration, } \\
\text { stomatal } \\
\text { regulation }\end{array}$ & Leaf diseases \\
\hline Reallocation & Leaf diseases \\
\hline \multicolumn{2}{|l|}{ Morphogenesis } \\
\hline Organ initiation & Mycoplasma, galling aphids \\
\hline Dwarfing & Viruses, fungi, nematodes \\
\hline Elongation & Fungi \\
\hline
\end{tabular}

canopy must be included in the model. In fact, radiation is the dominant source of spatial heterogeneity of assimilation rate in a crop canopy, more so than wind, temperature or $\mathrm{CO}_{2}$.

In addition to variation in irradiance or other external factors, leaf properties themselves may vary. One of the best known examples is that of leaf nitrogen, which affects leaf photosynthetic capacity. It is hypothesized that leaf nitrogen content responds positively to average leaf illumination.

\section{Summarizing the results of detailed models into one equation}

As shown in a review by Kimball (1983), responses at the single leaf level to $\mathrm{CO}_{2}$ are carried over to crop yield, and can be summarized by a mean $40 \%$ increase in dry matter for $\mathrm{C}_{3}$ crops upon doubling of $\mathrm{CO}_{2}$, and by $15 \%$ for $\mathrm{C}_{4}$-crops. A similar overall response for a $\mathrm{C}_{3}$ crop was simulated by means of a physiology based model (Goudriaan et al., 1985). This model showed that the resulting overall carbon response could be well described by a logarithmic response to ambient $\mathrm{CO}_{2}$ :

$$
Y=Y_{\mathrm{o}}\left[1+\beta \ln \left(C / C_{\mathrm{o}}\right)\right]
$$

where $Y$ stands for biomass, and $C$ for $\mathrm{CO}_{2}$ concentration during growth. The subscript o refers to standard conditions at $350 \mu \mathrm{mol} \mathrm{mol}^{-1}$ of $\mathrm{CO}_{2}$. This equation is only descriptive and has no physiological meaning in itself, but it summarizes many observations and simulation results. The response faetor $\beta$ - of modelled - erop dry weight was found to be $0.5=0.7$ dependent on whether the increased carbon gain was reinvested in productive plant material, or just stored in passive organs such as tubers. 


\section{YLELD REDUCTION BY PESTS AND DISEASES}

\section{Simple models}

Depending on its purpose, modelling can be done at various levels of complexity. In many situations, the approach of describing accumulated dry matter as the integral of intercepted radiation times a radiation conversion coefficient (Russell et al., 1989) is sufficient. Rossing et al. (1992) and van Oijen (1991) successfully applied this approach to explain the main route of damage by potato late blight (Phytophthora infestans). Such a simplified summarizing, approach is equally valid as a detailed reductionist approach in which a complex simulation model is used. It just depends on whether one is interested in the main outline, or in fine (and sometimes decisive) detail. An example of the summarizing approach is the expolinear equation (Goudriaan \& Monteith, 1990) which could be successfully applied to describe the effect of $\mathrm{SO}_{2}$ fumigation on the dry matter accumulation of a Faba bean crop (Fig. 5 and Table 3).

\section{Step-wise modelling of a range of impacts}

More insight was obtained when the analysis was deepened in the reductionist manner, leading to the conclusion that the reduction in growth rate was largely due to a reduction in light interception (Kropff et al., 1989), mediated by reduced leaf area formation. Leaf photosynthesis itself was not significantly affected by $\mathrm{SO}_{2}$. Likewise, honeydew had no effect on leaf photosynthesis in sugar beet (Hurej \& van der Werf, 1993a,b) or in winter wheat (Rossing \& van de Wiel, 1990). In such a situation the effect of $\mathrm{CO}_{2}$ cannot be expected to exhibit any interaction with the growth-reducing factor through photosynthesis, but other interactions remain possible. The growth reducing effects by pests and diseases can be grouped according to their injury mechanism (Table 2).

In crop growth models, daily assimilation tends to exert a feed-back on the formation of new leaf area. This positive feed-back can amplify early effects on leaf

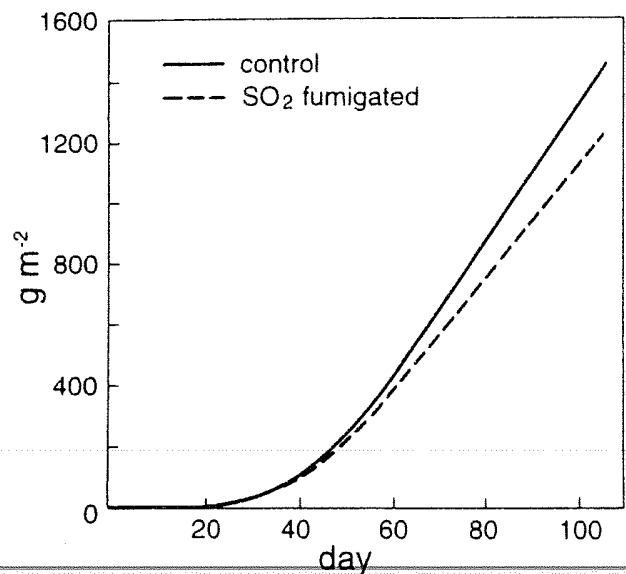

Fig. 5. Schematic representation of expolinear curves of the development of shoot dry matter in two crops of Faba bean, with and without $\mathrm{SO}_{2}$ fumigation. After Goudriaan and Monteith (1990).
Table 3. Parameter values for Faba bean data, fitted to the expolinear equation and plotted in Fig. 5. Oniy linear growth rate was significantly different. From Kropff et al. (1989)

\begin{tabular}{|c|c|c|}
\hline & Control & Fumigated \\
\hline Maximum relative growth rate $\left(\mathrm{d}^{-1}\right)$ & $0 \cdot 127$ & $0 \cdot 128$ \\
\hline Maximum linear growth rate $\left(\mathrm{g} \mathrm{m}^{-2} \mathrm{~d}^{-1}\right)$ & $22 \cdot 5$ & $18 \cdot 8$ \\
\hline $\begin{array}{l}\text { Intercept of linear growth with the } \\
\text { time axis (d) }\end{array}$ & $41 \cdot 3$ & $40 \cdot 1$ \\
\hline
\end{tabular}

photosynthesis by causing a reduction of light interception later on. Separation of immediate effects and accumulated feed-back effects is often difficult, even for the modeller himself, let alone that he could credibly convey his explanation to others. In such a situation modelling is best done in stages, introducing feed-back processes step by step.

First a model run is made for a reference time pattern of leaf area. In a second model run, the pest or disease is introduced, but with an effect on the time course of LAI only. Any modelled reduction in comparison with the reference run that we observe now is entirely due to the modelled reduction of light interception. If a gap remains, this must be due to systemic effects of the disease on plant functioning, such as through reduced leaf photosynthesis (van Roermund \& Spitters, 1990; Bastiaans \& Kropff, 1991; Bastiaans \& Roumen, 1993).

Interaction of $\mathrm{CO}_{2}$ and a growth reducing agent may not only occur via the direct routes of attack, such as would apply to the group of organisms that affect the carbon economy (Table 2). $\mathrm{CO}_{2}$ can also help to overcome effects in other groups of processes. For instance, the positive effect of $\mathrm{CO}_{2}$ on the water economy may help to mitigate the growth reduction due to nematodes (Schans, 1991). Also, the partial stomatal closure induced by $\mathrm{CO}_{2}$ may render plants less susceptible to access from the ambient air with eventual damaging pollutants, or to entry of pathogens (Royle \& Thomas, 1971; Ramos \& Volin, 1987). High $\mathrm{CO}_{2}$ levels stimulate cereal rusts and reduce latency periods up to $c .0 \cdot 3 \% \mathrm{CO}_{2}$ (Gassner \& Straib, 1923). Several soil-borne pathogenic fungi can fix $\mathrm{CO}_{2}$ (e.g. Parkinson et al., 1991). The net effect of an increase in atmospheric $\mathrm{CO}_{2}$ on fungal pathogens and crop yield cannot yet be predicted.

\section{CLIMATE AND GEOGRAPHICAL DISTRIBUTION OF CROPS, PESTS AND DISEASES}

\section{Distribution maps of crops}

A warmer climate will obviously have large consequences for the distribution of vegetation and indeed of agriculture (Kenny et al., 1993) on earth. In these agricultural studies the degree-day approach is often used. Crops need a species dependent amount of 'heat' to reach growth stages such as flowering and maturation. Above a minimally required base temperature $\left(T_{\mathrm{b}}\right)$ crop development proceeds approximately propor- 
Table-4. Required and-available-temperature-sums, expressed-in-degree-days. Temperature-sums-are-calculated by accumulating the number of degrees Centigrade above a base temperature for each day of the growing season. Base temperature and required temperature sum are crop speeifie

\begin{tabular}{lcccc}
\hline & Spring wheat & Early potato & Silage maize & Sunflower \\
\hline Base temperature & 0 & 2 & 6 & $7 \cdot 2$ \\
Required temperature sum & 1700 & 1250 & 1460 & 1300 \\
Available temperature sum per region & & & & \\
$\quad$ Iceland & 1590 & 1100 & 370 & 215 \\
$\quad$ Netherlands (De Bilt) & 3410 & 2690 & 1610 & 1340 \\
France: & & & 1750 & 1390 \\
$\quad$ Brest & 3930 & 3200 & 1850 & 1590 \\
$\quad$ Strassbourg & 3550 & 2890 & 2010 & 1730 \\
$\quad$ Dijon & 3830 & 3120 & 2230 & 1940 \\
$\quad$ Lyon & 4140 & 3410 & & \\
\hline
\end{tabular}

tionally to temperature (at least up to a species dependent optimum level). This means that the accumulated amount of surplus temperature is a good measure for the amount of crop development reached. An example of the result of such a calculation for grain maize, sunflower and potato is given in Table 4 for a few locations in Europe. The potato crop appears to be particularly suitable for a cool climate because it can be harvested even before it has completed its growing cycle. Even on Iceland tuber formation can proceed for a short period before the growing season ends. In The Netherlands, potatoes, Faba bean, spring wheat and sugar beet (not shown) can be grown without any difficulty, but sunflower cultivation is barely possible. In practice we will see crop failure in too many summers due to adverse cold weather. Also for silage maize the surplus is very small (not shown), but in view of the destination as fodder grain its maturation does not really matter.

This type of study can be extended to a very detailed geographical map. Kenny and Harrison (1993) found that the northern limit of cultivation of maize will shift to the north by about $300 \mathrm{~km}$ for each degree Celsius of temperature increase. In the coastal zone with a maritime climate the effect on the length of the growing season is larger than in the continental centre zone, where the winters are far too cold anyway. It was found that the northern limit of grain maize cultivation would reach the middle of Sweden upon a temperature increase of $3^{\circ} \mathrm{C}$.

Shifts in geographical distribution of pests and diseases Sutherst (1991) used a computerized system, CLIMEX, to produce world-wide maps of an ecoclimatic index EI which integrates growth potential within the limiting effects of extreme climatic conditions. The global distribution of weeds, pests and diseases has been studied thoroughly, be it only for quarantine purposes. Many crops, transferred from one continent to another, left their harmftl-agents-behind, at least-temporarily. Later, these agents may ove their hosts often with disas trous economic consequences. The sobering conclusion is that most weeds, pathogens, and pests thrive where the host crop thrives. Potato late blight is dangerous in
Mexico, where it came from, in the Netherlands where it came to, but also in the Israelian Negev - a semi-arid area-where potatoes thrive when irrigated.

Nevertheless, the question remains whether we can predict where weeds, pests and diseases may reach the nuisance value. Yes we can (Zadoks, 1991). Weltzien (1972) applied the principles of geophytopathology to sugar-beet mildew, indigenous in Europe, and predicted that California would be a suitable ecotope. A few years later it appeared in California and stayed.

The adaptability of pest and disease organisms and weeds is tremendous, and maybe they exploited as little of their genetic variability as we did of crop plants. Ecotypes do exist but are poorly studied. The Colorado beetle (Leptinotarsa decemlineata) seems to have developed into a number of ecotypes in North America according to survival conditions (Hsiao, 1988). Most weeds, pests and diseases of the temperate zone can also be found in the tropics at high altitude, say $>3000 \mathrm{~m}$. There they are exposed to high UV radiation, at levels which may kill the same pathogens in the UK (Puccinia striiformis; Maddison \& Manners, 1972). The lesson is that, if the ozone layer fails, the pathogens may adapt. Similarly, yellow stripe rust $(P$. striiformis), usually extremely sensitive to air pollution, has adapted in Western Europe to air pollution (Stubbs, 1985). Obviously, genetic variation for resistance to adverse conditions is tremendous in weeds, pests and pathogens.

In conclusion, if a crop grows well, the microclimate of the crop favours the standard pests and diseases of that crop. Nitrogen level, stand density and plant ideotype are modifiers with known or supposed effects on the multiplication rate of and thus on the damage done by harmful agents. The mesoclimate determines the rate of oversummering or overwintering of pests and diseases. In this area, the adaptability of pests and diseases seems incredibly large but little studied yet.

\section{Combined effects of climatic change}

If climate changes, this means in practice that existing elimatic zones shift places If this change proceeds as slowly as anticipated, the rather mobile pests and diseases will follow without delay (Table 5). For the less mobile soil-borne pests and diseases there may be a 
Table-5-Displacement rates-in-metres or-kilometres per-growing season

Zero order epidemics (foci)

Forest trees after last glacial period

Climate zones (due to greenhouse effect)

Maize frontier in Europe (due to breeding)

Second order epidemics - insects

First order epidemics - fungi

Second order epidemics - fungi

${ }^{a}$ van den Bosch et al. (1988)

${ }^{b}$ Ketner (1990).

'Authors' estimate.

${ }^{d}$ Kampmeijer and Zadoks (1977).

${ }^{e}$ Heesterbeek and Zadoks (1987).

welcome delay. Don't be lured into false hope for slow dispersal of pathogens, pests, or weeds, because all are subject to dual or multiple dispersal (Zawolek \& Zadoks, 1992). Though the best studied dispersal mechanism may cover short distances only, but at high frequency, most harmful organisms also have at least one long distance-low frequency dispersal mechanism. In these higher order dispersal mechanisms man is often instrumental. Weeds need not but may react differently. Migration rates may be slow because the propagules are heavy, and because weeds face competition where they arrive.

Climatic change implies that at any location the season may become warmer or colder, wetter or dryer, longer or shorter (Ketner, 1990). More important than changes in radiation and precipitation may be changes in the duration of the cropping season, since polycyclic pests and diseases need time to build up their population. Longer vegetation periods will be conducive to more damage by polycyclic agents. The same may be true for some weeds of a polycyclic nature, that is with more generations per year such as common chickweed (Stellaria media), annual poa (Poa annua) and groundsel (Senecio vulgaris) (Ketner, 1990).

Ketner (1990) states that with climatic change present vegetations may dissolve and new associations form. Whatever will happen is largely determined by characteristics of individual weed species. Given the parameters, with due attention for aestivation, hibernation and dispersal, ecosystem changes are amenable to modeling and dynamic simulation. Ecological relationships at the di- and tritrophic level will be changed

Table 6. Responses of brown plant hopper (Nilaparvata lugens, macropterous females), a pest of rice and two of its predators, Cyrtorhinus lividipennis (females) and the wolf spider (Pardosa pseudoannulata). Responses are expressed as mortality versus time at $40^{\circ} \mathrm{C}$ and subjected to probit analysis. $L T_{50}=$ lethal time in hours. Slope $=$ slope of probit line. n.s. = non significant regression. After Heong and Domingo (1992)
(Liljelund, 1990). With climatic change especially in the tropics, predator-prey may be affected (Table 6; Heong \& Domingo, 1992). These effects can be modelled when food webs in tropical agro-ecosystems will be parametrized. Genetic variability is large in weeds (first trophic level) and possibly also in organisms of the second and third trophic level. The effect of selection for adapted ecotypes cannot yet be foreseen.

\section{Some cautionary remarks}

Since the 1973 oil crisis, $\mathrm{CO}_{2}$ fertilization (Enoch \& Kimball, 1986) is customary in commercial greenhouses in The Netherlands, especially for growing lettuce. Generally speaking, the $\mathrm{CO}_{2}$ concentration was increased from $0.03 \%$ to $0.08 \%$. No adverse effects are on record with respect to pests and diseases (Glasshouse Crops Research Station, Naaldwijk, personal communication). High $\mathrm{CO}_{2}$ may reduce the number of greenhouse whiteflies due to a higher $C: N$ ratio (Tripp et al., 1992).

The number of clear-cut examples where climatic change gave a shift in pest and disease patterns is very limited. A well documented case is a series of yellow stripe rust outbreaks in Washington State, associated with a set of cooler and moister years (Coackley et al., 1983).

A false alarm is the rumour that the present expansion of white fly and white fly transmitted gemini viruses from the tropics northward is due to climatic change. A more realistic explanation is the wide-spread use of synthetic pyrethroids, which effectively wiped out the predators and parasitoids of white fly. Similarly, the curious shift from Septoria glume blotch to Septoria speckled leaf blotch on wheat, observed over a long period in The Netherlands, seems nitrogeninduced and not climate-induced (Zadoks, unpublished).

\section{FINAL REMARKS}

Modelling of crop growth and of pests, diseases and weeds is based on understanding formative processes and their causal linkages. Intellectually this approach is more appealing and appears more promising than analysis by statistical methods. However, there is still a long way to go. Not only crop growth must be simulated, but also pests, diseases and weeds, and the interactions between these harmful agents and their host crops. Although individual models for crop growth appear to have been validated at field level, Daamen and Jorritsma (1990) found that the predictive performance of various models at the regional level was still disappointing. It is the explicit objective of the IBPG/GCTE program (Steffen et al., 1992) to improve this rather unsatisfactory situation.

Detailed study of the-monecyclic, polycyclic-and polyetic adaptability to elimatie-change of pest, diseases and weeds, and of beneficials to control them, is needed so that we will be better equipped to face the future. The volatility of disease outbreaks necessitates careful, long-

$\begin{array}{lrr}\text { N. lugens } & 47.3 & 3.4 \\ \text { C. lividipennis } & 2.8 & 11.0\end{array}$

P. pseudoannulata $>280 \cdot 0$ n.s.

0




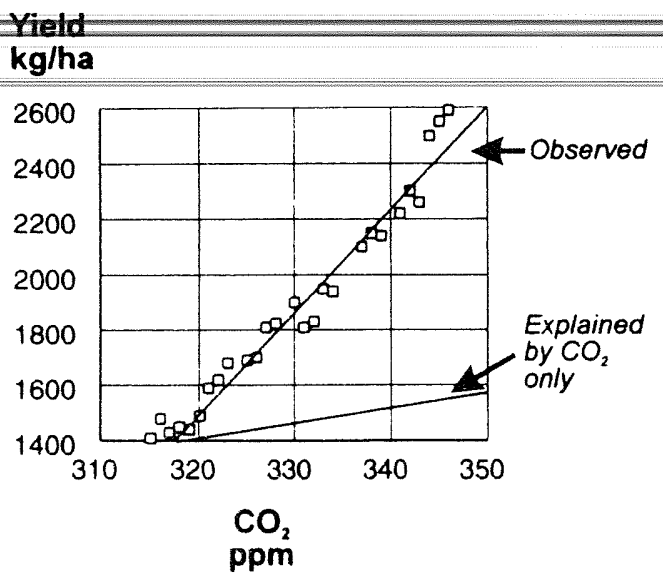

Fig. 6. Average world-wide grain yields (observed) and the yield increase explained by the rise in $\mathrm{CO}_{2}$ concentration. From Rabbinge et al. (1993).

term observations of epidemiological factors. Modeling can contribute, but requires sound knowledge of the causal factors determining spatial distribution, survival, reproduction, dispersal and infliction of damage. Such knowledge is still not sufficiently available.

The dynamics of modern society induce faster changes than the surmized greenhouse effect, as is exemplified by the 'urban heat islands'. Agricultural technology has tremendous possibilities and can yet easily match the ill-effects of global change (Fig. 6). Modelling is one of several ways to guide our judgement.

\section{REFERENCES}

Aber. J. D. \& Melillo, J. M. (1991). Terrestrial Ecosystems. Saunders College Publishing. Philadelphia. PA.

Arp. W. J. (1991). Vegetation of a North American Salt Marsh and Elevated Atmospheric Carbon Dioxide. Vrije Universiteit, Amsterdam, 181 pp.

Arp. W. J. \& Drake. B. G. (1991). Increased photosynthetic capacity of Scirpus olneyi after 4 years of exposure to elevated $\mathrm{CO}_{2}$. Plant. Cell \& Environ., 14, 1003-6.

Bastiaans, L. \& Kropff. M. J. (1991). Understanding and quantifying damage by air pollution and leaf blast. IRRI Research Papers, 151, 21-26.

Bastiaans. L. \& Roumen. E. C. (1993). Effect of leaf photosynthetic rate by leaf blast for rice cultivars with different types and levels of resistance. Euphytica, 66. $81-87$.

Boote, K. J., Jones. J. W., Mishoe, J. W. \& Berger, R. D. (1983). Coupling pests to crop growth simulators to predict yield reductions. Phytopathol., 73, 1581-7.

Boote. K. J., Batchelor, W. D.. Jones. J. W., Pinnschmidt, H. \& Bourgeois, G. (1993). Pest damage relations at the field level. In Systems Approaches for Agricultural Development, ed. F. W. T. Penning de Vries, P. Teng \& K. Metselaar. Kluwer, Dordrecht.

Campbell, W. J., Allen, L. H. \& Bowes, G. (1988). Effects of $\mathrm{CO}_{2}$ concentration on Rubisco activity, amount, and photosynthesis in soybean leaves. Plant Physiol., 88, $1310-16$

Coackley, S M Line R.F.\& Boyd, W. S. (1983). Regional models for predicting stripe rust on winter wheat in the Pacific Northwest. Phytopathol., 73, 1382-5.

Daamen, R. A. \& Jorritsma, I. T. M. (1990). Effects of powdery mildew and weather on winter wheat yield. 1 .
Variation of weather between years Netherlands $J$ Plant Pathol., 96, 29-34.

de Wit, C. T. (1992), Resouree use effieieney in agriculture. Agric. Sys., 40, 125-51.

Dik, A. J., Fokkema, N. J. \& van Pelt, J. A. (1991). Consumption of aphid honeydew, a wheat yield reducing factor, by phyllosphere yeasts under field conditions. Netherlands J. Plant Pathol., 97, 209-32.

Downton, W. J. S. (1975). The occurrence of $C_{4}$ photosynthesis among plants. Photosynthetica, 9, 96-105.

Ehret, D. L. \& Jolliffe, P. A. (1985). Photosynthetic carbon dioxide exchange of bean plants grown at elevated carbon dioxide concentration. Can. J. Bot., 63, 2026-30.

Enoch, H. Z. \& Kimball, B. A. (1986). $\mathrm{CO}_{2}$ Enrichment of Greenhouse Crops, Vols 1 and 2. CRC Press, Boca Raton, FL.

Farquhar, G. D. \& von Caemmerer, S. (1981). Modelling of photosynthetic response to environmental conditions. In Encyclopedia of Plant Physiology, New Series, Vol. 12B. ed. A. Pirson \& M. H. Zimmermann. Springer, Berlin.

Gassner, G. \& Straib, W. (1929). Untersuchungen über die Abhängigkeit des Infektionsverhaltens der Getreiderostpilze vom Kohlensauregehalt der Luft. Phytopathologische Zeitschrift, 1, 1-30.

Gifford, R. M. (1979). Growth and yield of carbon dioxideenriched wheat under water-limited conditions. Australian J. Plant Physiol., 6, 367-78.

Goudriaan, J. \& Bijlsma, R. J. (1987). Effects of $\mathrm{CO}_{2}$ enrichment on growth of faba beans at two levels of water supply. Netherlands J. Agric. Sci., 35, 189-91.

Goudriaan, J. \& Monteith, J. L. (1990). A mathematical function for crop growth based on light interception and leaf area expansion. Ann. Bot., 66, 695-701.

Goudriaan, J. \& Unsworth, M. H. (1990). Implications of increasing carbon dioxide and climate change for agricultural productivity and water resources. In Impact of Carbon Dioxide, Trace Gases, and Climate Change on Global Agriculture. American Society of Agronomy, Special Publication No. 53, pp. 111-30.

Goudriaan, J., van Laar, H. H., van Keulen, H. \& Louwerse, W. (1985). Photosynthesis, $\mathrm{CO}_{2}$ and plant production. In Wheat Growth and Modelling, ed. W. Day \& R. K. Atkin. NATO ASI Series, Series A: Life Sciences, Vol. 86. Plenum Press, New York, pp. 107-122.

Heesterbeek. J. A. P. \& Zadoks, J. C. (1987). Modelling pandemics of quarantine pests and diseases; problem and perspectives. Crop Protection, 6, 211-21.

Heong. K. L. \& Domingo. I. (1992). Shifts in predator-prey ranges in response to global warming. IRRI Rice Res. Nells Let., 17(6), 29-30.

Holm, E. G., Plucknett, D. L., Pancho, J. V. \& Herberger, J. P. (1977). The World's Worst Weeds. East-West Center Book, Honolulu.

Houghton, J. T., Jenkins, G. J. \& Ephraums, J. J. (1990). Climate Change. The IPCC Scientific Assessment. Cambridge University Press, Cambridge, $365 \mathrm{pp}$.

Hsiao, T. H. (1988). Host specificity, seasonality and bionomics of Leptinotarsa beetles. In Biology of Chrysomelidae, ed. E. Jolivet, E. Petitpierre \& T. H. Hsiao, Kluwer, Dordrecht. pp. 581-99.

Hurej, M. \& van der Werf, W. (1993a). The influence of black bean aphid. Aphis faba Scop., and its honeydew on the photosynthesis of sugar beet. Ann. App. Biol., 122. 189-200.

Hurej, M. \& van der Werf, W. (1993b). The influence of black bean aphid, Aphis faba Scop., and its honeydew on leaf growth and dry matter production of sugar beet Ann Appl. Biol. 122, 201-14

Kampmeijer, $\mathrm{P}$ \& Zadoks, J $\mathrm{C}$ (1977) EPIMUL, a Simulator of Foci and Epidemics in Mixtures, Multilines and Mosaics of Resistant and Susceptible Plants. Simulation Monographs, Pudoc, Wageningen, $50 \mathrm{pp}$. 
Kenny G J \& Harrison, P A (1993). Analysis of effects of climate change on broadscale patterns of agroclimate in Europe. In The Effect of Climate Change on Agricultural and Horticultural Potential in Europe, ed. G. J. Kenny, P. A. Harrison \& M. L. Parry, Environmental Change Unit, Oxford, $224 \mathrm{pp}$.

Kenny, G. J., Harrison, P. A. \& Parry, M. L. (eds) (1993). The Effect of Climate Change on Agricultural and Horticultural Potential in Europe. Environmental Change Unit, Oxford, $224 \mathrm{pp}$.

Ketner, P. (1990). Impact of climate change on flora and vegetation in Western Europe with special emphasis on the Netherlands. In Effects of Climate Change on Terrestrial Ecosystems, ed. J. I. Holten. NIA Norsk Institutt for Naturforskning. Trondheim, pp. 47-60.

Kimball, B. A. (1983). Carbon dioxide and agricultural yield: An assemblage and analysis of 430 prior observations. Agron. J., 75, 779-88.

Kropff, M. J., Mooi, J., Goudriaan, J., Smeets, W., Leemans, A.. Kliffen, C. \& van der Zalm, A. J. A. (1989). The effects of long-term open-air fumigation with $\mathrm{SO}_{2}$ on a field crop of broad bean (Vicia faba L.). New Phytol., 113 , $337-44$.

Larigauderie, A., Hilbert, D. W. \& Oechel, W. C. (1988). Effect of $\mathrm{CO}_{2}$ enrichment and nitrogen availability on resource acquisition and resource allocation in a grass, Bromus mollis. Oecologia, 77, 544-9.

Lemon, E. R. (ed.) (1983). CO, and Plants. AAAS Selected Symposium No. 84. Westview Press. Boulder. Co.

Liljelund. L. E. (1990). Effects of climate change on species diversity and zonation in Sweden. In Effects of Climate Change on Terrestrial Ecosystems, ed. J. I. Holten. NIA Norsk Institutt for Naturforskning. Trondheim, pp $43-47$

Loomis. R. S. \& Connor, D. J. (1992). Crop Ecology. Cambridge University Press. Cambridge.

Maddison, A. C. \& Manners, J. G. (1972). Sunlight and viability of cereal rust uredospores. Transactions of the British Mvcological Societv, 59. 429-43.

Moore, P. D. (1982). Evolution of photosynthetic pathways in flowering plants. Nature, 295, 647-8.

Morison, J. I. L. (1987). Intercellular $\mathrm{CO}_{2}$ concentration and stomatal response to $\mathrm{CO}_{2}$. In Stomatal Function, ed. E. Zeiger, G. D. Farquhar \& I. R. Cowan. Stanford University Press, Stanford. CA.

Mortensen, L. M. (1983). Growth responses of some greenhouse plants to environment. $\mathrm{X}$ Long-term effect of $\mathrm{CO}_{2}$ enrichment on photosynthesis, photorespiration, carbohydrate content and growth of Chrisanthemum morifolizm Ramat. Sci. Rep. of the Agric. Univ. of Norway. Vol 62. Report No 272.

Nambudiri, E. M. V., Tidwell. W. D., Smith, B. N. \& Hebbert, N. P. (1978). A $C_{+}$plant from the Pliocene. Nature, 276, 816-7.

Parkinson, S. M., Jones, R.. Maharg, A. A.. Wainright, M. \& Killham, K. (1991). The quantity and fate of carbon assimilated from ${ }^{14} \mathrm{CO}$, by Fusarium oxvsporum grown under oligotrophic and near-oligotrophic conditions. Mycolog. Res., 95, 1345-49.

Peñuelas, J. \& Matamala, R. (1990). Changes in $\mathrm{N}$ and $\mathrm{S}$ leaf content. stomatal density and specific leaf area of 14 plant species during the last three centuries of $\mathrm{CO}_{2}$, increase. $J$. Exp. Bot., 41, 1119-24.

Poorter. H. (1993). Interspecific variation in the growth response of plants to an elevated ambient $\mathrm{CO}_{2}$ concentration. Vegetation, 104/105, 77-97.

Rabbinge, $R$ van Latesteijn, H C \& Goudriaan. J. (1993). Assessing the greenhouse effect in agriculture. In Environ. Change and Human Heath ICIBA Foundation Symposium 175). John Wiley, Chichester, pp. 62-79.

Ramos. L. J. \& Volin, R. B. (1987). Role of stomatal opening and frequency on infection of Lycopersicon spp. by Xanthomonus campestris pv. vesicatoria. Phvtopathol.

77, 1311-17.

Raschke, K (1975) Stomatal action Ann Rev Plant Physiol. 26, 309-40.

Rossing, W. A. H. \& van de Wiel, L. A. J. M. (1990). Simulation of damage in winter wheat caused by the grain aphid Sitobion avenae. 1. Quantification of the effects of honeydew on gas exchange of leaves and aphid populations of different size on crop growth. Netherlands J. Plant Pathol., 96, 343-64.

Rossing. W. A. H., van Oijen, M., van der Werf, W., Bastiaans, L. \& Rabbinge, R. (1992). Modelling the effects of foliar pests and pathogens on light interception, photosynthesis, growth rate and yield of field crops. In Pests and Pathogens, ed. P. G. Ayres. Environmental Plant Biology Series, Bios Scientific Publishers.

Royle, D. J. \& Thomas, G. G. (1971). The influence of stomatal opening on the infection of hop leaves by Pseudoperonospora humuli. Observations with the scanning electron microscope on the early stages of hop leaf infection by Pseudoperonospora humuli. Physiol. Plant Pathol., 1 $329-43,335-49$

Russell, G., Jarvis, P. G. \& Monteith, J. L. (1989). Absorption of radiation by canopies and stand growth. In Plant Canopies, ed. G. Russell, B. Marshall \& P. G. Jarvis. Society for Experimental Biology Seminar Series. No 31, Cambridge University Press, Cambridge, pp. 21-39.

Schans, J. (1991). Reduction of leaf photosynthesis and transpiration rates of potato plants by second-stage juveniles of Globodera pallida. Plant, Cell \& Environ. $14,707-12$

Spitters, C. J. T. Toussaint, H. A. J. M. \& Goudriaan, J. (1986). Separating the diffuse and direct component of global radiation and its implications for modeling canopy photosynthesis. Part 1 . Components of incoming radiation. Agric. For. Meteorol., 38, 217-29.

Steffen. W. L., Walker, B. H., Ingram, J. S. I. \& Koch, G. W. (1992). Global Change and Terrestrial Ecosystems, The Operational Plan. IGBP Report 21, IGBP/ICSU, Stockholm.

Stubbs, R. W. (1985). Stripe rust. In The Cereal Rusts, Vol. II. Diseases, Distribution, Epidemiology, and Control, ed. A. P. Roelfs \& W. R. Bushnell. Academic Press, Orlando. FL. pp. $61-101$

Sutherst, R. W. (1991). Pest risk analysis and the greenhouse effect. Rev. Agric. Entomol., 79, 1177-87.

Tripp, K. E., Kroen, W. K., Peet, M. M. \& Willits, D. H. (1992). Fewer whiteflies found on $\mathrm{CO}_{2}$-enriched greenhouse tomatoes with high $\mathrm{C}: \mathrm{N}$ ratios. HortScience, 27. 1079-80.

Valle, R., Mishoe, J. W.. Campbell, W. J., Jones, J. W. \& Allen L. H. (1985). Photosynthetic responses of 'Bragg soybean leaves adapted to different $\mathrm{CO}$, environments. Crop Sci. 25, 333-9.

van den Bosch, F. Metz, J. A. J., Frinking, H. D. \& Zadoks. J. C. (1988). Focus expansion in plant disease. III. Two experimental examples. Phytopathol., 78, 919-25.

van der Burgh, J., Visscher, H., Dilcher, D. L. \& Kürschner, W. M. (1993). Paleatmospheric signatures in neogene fossil leaves. Science, 260, 1788-90.

van der Werf, W., Bastiaans, L., Rossing, W. A. H. \& Rabbinge, R. (1990). Modelling crop response to growth reducing factors. In Proc. Int. Symp. on Biotic Stress of Barley in Arid and Semi-arid Environments. Montana State University, Montana, and ICARDA, Syria.

van Oijen, M. (1991). Light use efficiencies of potato cultivars with late blight (Phytophtora infestans). Potato Res. 34. 123-32

van Roermund, H. J. W. \& Spitters, C. J. T. (1990). Simulation of yield reduction by leaf rust in winter wheat, applied to the analysis of genetic variation in partial resistance. Netherlands J. Plant Pathol., 96, 17-28. 
Weltzien H C (1972) Geophytopathology Ann Rev Phytopathol., 10,277-98.

Wong, S.C. (1979). Elevated atmospherie partial pressure of $\mathrm{CO}_{2}$ and plant growth. I. Interactions of nitrogen nutrition and photosynthetic capacity in $\mathrm{C}_{3}$ and $\mathrm{C}_{4}$ plants. Oecologia, 44, 68-74.
Zadoks, J C (1991) Coping with climatic variation in plant disease control. In Climate and Food Security. Manila, International Rice Research Institute, pp. 269-76.

Zawolek, M. W. \& Zadoks, J. C. (1992). Studies in focus development: An optimum theorem for the dual dispersal of plant pathogens. Phytopathol., 82, 1288-97. 